\title{
CUATRO IMÁGENES DE PLATA PROCEDENTES DE LA CÁMARA DE LA REINA ISABEL LA CATÓLICA, EN LA CATEDRAL DE TOLEDO
}

\author{
POR \\ MARGARITA PÉREZ GRANDE \\ Lda. en Historia del Arte
}

In 1536 the Duchess of Medinasidonia sold a group of silver objects to the Cathedral of Toledo. It has not been previously published that among these objects were several devotional images acquired years earlier at the auction of Queen Isabel la Católica property after her death. This study is centered on aspects of the four pieces still existing (materials, typology, aesthetic, characteristics and prices). However, it also attempts to analyze the entire group of pieces in context, using documents which refer to the pieces as well as the heraldic shields on their pedestals. It has been determined that only some of the images were made during the times of Queen Isabel. The rest came from family inheritances dating to the early 15 th century.

Las imágenes que van a ser objeto de este estudio representan a la Virgen con el Niño, San Pedro, San Pablo y San Sebastián. El origen que les hemos atribuido se fundamenta, de una parte, en diferentes noticias documentales contenidas en las cuentas de la tesorería de la reina Isabel y de su testamentaría, y también en el Archivo de Obra y Fábrica de la propia Catedral de Toledo. De otra, en los escudos y divisas que originalmente llevaba cada una en su peana, sólo conservados ahora en las imágenes de San Sebastián y de la Virgen.

Fueron adquiridas por la Catedral de Toledo en 1535, como parte de un conjunto de piezas de platería que vendió la Duquesa de Medinasidonia, doña Mencía de Guzmán, integrado además por otras siete imágenes, dos blandones, una naveta con su cuchara y un acetre con su hisopo; el precio de todo lo cual ascendió a $881.887 \mathrm{mrs} .{ }^{1}$. Por la descripción que se hace de estas piezas en el libro de gastos y en los sucesivos inventarios del Sagrario de la Catedral, sabemos que todas las imágenes menos una llevaban escudos con las armas reales. Esta circunstancia nos hizo suponer que muy bien podia tratarse de las mismas imágenes compradas, treinta años antes, por el difunto esposo de doña Mencía (don Pedro Girón, conde de Ureña) en la almoneda de

1 Archivo de Obra y Fabrica de la Catedral de Toledo [A.O.F.C.T.] (862). Libro de Frutos y Gastos, 1533 , fol. 51. No es errónea la fecha del libro, pues la cuenta de 1535 se encuentra incluida aquí, en la partida de "Oro, seda, plata y brocado". 
bienes de la reina Isabel la Católica. Lo que ha quedado confirmado por la total coincidencia en la identidad de los personajes representados, y en el dato del peso y otros detalles, tal como éstos se describen en la testamentaria real ${ }^{2}$.

Ninguna de las cuatro imágenes conservadas presenta marcas que correspondan a su época de realización, lo que impide determinar el lugar, autor y fecha exacta en que se hicieron. No obstante, el contenido de los escudos ha permitido precisar algo más la cronología, de éstas y de las otras imágenes compradas por la Catedral toledana a doña Mencía. Por otro lado, es probable que alguna de ellas pueda relacionarse con el libramiento efectuado en 10 de enero de 1489 a favor del tesorero de la Reina, Ruy López de Toledo, para pagar «çiertos apóstoles de plata, que Su Altesa mando haser» (le entregaron el equivalente a 287.000 mrs. de la plata que Gonzalo de Baeza, otro de los tesoreros reales, había recibido de las rentas del año 1487). Posteriormente, cuando en 17 de septiembre de 1492 se hizo cuenta con el platero de Salamanca, Pedro de Dueñas, por la realización de una imagen de San Francisco, consta que la hechura se le pagaba por mandato de la Reina «al preçio que el thesorero Ruy Lopez pago por la hechura de cada marco de plata de çiertos Apostoles que hizo haser; e paresçe, por testimonio sygnado de escrivano publico, quel dicho thesorero pago por cada marco de plata de los dichos Apostoles a 1000 mrs.» (Dueñas había recibido ya a cuenta de esta obra 60.000 mrs. en 1490) ${ }^{3}$.

\section{Las imágenes devocionales de plata de la Reina Isabel}

El Conde de Ureña compró en la almoneda real un total de doce imágenes de plata sobredorada: San Juan Bautista, San Juan Evangelista, Santiago el Mayor, San Pedro, San Andrés, San Sebastián, San Felipe, San Pablo, San Bartolomé, Virgen con el Niño, Santa María Magdalena, y un Santo Tomás que había pertenecido al Duque de Medinaceli, adquirido por la Reina en $1503^{4}$. Las dos citadas en último lugar no fueron vendidas después a la Catedral de Toledo pero, a cambio, doña Mencía de Guzmán añadió al conjunto una imagen de similares características de Santiago el Menor. No eran éstas, sin embargo, las únicas imágenes devocionales de plata que había poseído Isabel la Católica. En su testamentaría constan otras nueve -en algún caso de los mismos santos- de peso y, por lo mismo, hay que suponer que también de tamaño semejante a las citadas: las de Santo Domingo, San Jerónimo, San Andrés, San Antonio y la Virgen con el Niño, fueron adquiridas por Luis López; otra de San Jerónimo y una de San Lucas, las compró Pizarro (seguramente el platero Juan Pizarro que había trabajado al servicio de la Reina); dos imágenes más de las que habían pertenecido al Duque de Medinaceli -compradas también en 1503-, fueron adquiridas, respectivamente, por Luis López (San Pablo) y por el propio rey don Fernando (San Francisco). Se citan además tres imágenes pequeñas de Santo Tomás, de la Virgen de Montserrat y de la Virgen de Guadalupe, que pasaron asimismo a propiedad de Luis López ${ }^{5}$. También las cuentas de la tesorería de la Reina aportan mas noticias de otras imágenes debidas a encargos propios o para los miembros de su familia, en especial de la llamada reina-princesa doña Isabel $(+1498)$. Así, en 1484, Juan Pizarro percibió 80.165 mrs. por una imagen de la Virgen "para dar a Guadalupe». En 1492, se anota el empleo de 27 marcos, 1 onza y 2 ochavas «de plata de marca[r]" (6.346 g.), a los que se añadían 12 marcos, 6 onzas y 6 ochavas (2.954 g.) tomados de la cámara, "para haser dos ymagenes para la yglesia de la Seo de la-

\footnotetext{
2 Torre y del Cerro, A. de la: Testamentaría de Isabel la Católica, Valladolid, 1968, págs. 39-43.

3 Torre, A. de la; Torre, E. A. de la: Cuentas de Gonzalo de Baeza Tesorero de Isabel la Católica. I (1477-1491), Madrid 1955, pág. 182, 364; Idem, Cuentas... II (1492-1504), Madrid, 1956, págs. 33.

4 Idem, Cuentas... II (1492-1504), pág. 597.

5 Torre y del Cerro, A. de la: Testamentaría..., págs. 48, 67.
} 
çiudad de Barcelona»; el valor de la plata ascendía a $62.188 \mathrm{mrs}$. (a $2.290 \mathrm{mrs}$./marco), siendo el coste de fundirla de $320 \mathrm{mrs}$. ${ }^{6}$. El 13 de agosto de 1497 (aunque la cuenta se refiere al parecer a gastos del año 1495) se libró en Medina del Campo, al platero de la princesa doña Isabel, la cantidad correspondiente a una imagen de la Magdalena realizada a partir de otra de la Virgen, sirviendo el Niño que ésta sostenía para hacer una caja que la santa llevaría en la mano. En 1497-99, el platero Juan de Valladolid, realizaba "ciertas imágenes» -quizá las dos de San Jorge y San Juan evangelista que se mencionan en la partida del último año citado-, también para la princesa Isabel. En otro asiento, probablemente de 1502, se anota la existencia de unas imágenes de la Virgen, Santa Bárbara, Santa Catalina, Santo Domingo, Santo Tomás y San Pedro Mártir, que podrían ser las mismas a las que se reflere una nómina confeccionada en Zaragoza (1495-1512), principalmente sobre los gastos ocasionados por el viaje de la casa de la princesa a Portugal. Por último, en 1504, se hizo un libramiento en Medina del Campo a doña María de Velasco, esposa de Juan de Velázquez, por el gasto que había hecho «en ciertas imágenes compradas por mandado de la reina» 7 .

Todas estas noticias son buena muestra de la costumbre desarrollada en los principales centros europeos, especialmente a partir del siglo xIv, de realizar imágenes devocionales de tamaño pequeño y mediano (entre 25 y $60 \mathrm{~cm}$ de altura) en metal precioso, destinadas a los oratorios privados de reyes, príncipes, nobles y dignidades eclesiásticas. Estas imágenes suelen relacionarse con la iconografía de la conversación sacra, propia de las artes plásticas contemporáneas (el impresionante conjunto en bronce del altar de San Antonio de Padua, obra de Donatello en 1443-53, es uno de los ejemplos más notables que pueden citarse a este respecto), con una figura de la Virgen con el Niño centrando el conjunto, a ambos lados de la cual se sitúan apóstoles y/o santos de devoción particular, todos ellos en pie sobre una peana y sosteniendo en las manos objetos relacionados con su iconografía. Los centros religiosos más importantes se procuraron también piezas de esta índole, aunque lo habitual en este caso fue que las imágenes sirvieran a la vez como receptáculo de las reliquias del santo al que representaban: suelen aprovecharse con este fin los mismos objetos que la imagen portaba, abriendo en ellos viriles o utilizando piezas de cristal de roca en su configuración para que quedara manifiesto el contenido; en otras ocasiones, es la peana la que alberga reliquias en su interior. La propia Catedral de Toledo, por ejemplo, poseía ya algunas imágenes de estas características en la época de la compra a la Duquesa de Medinasidonia 8: en los inventarios se anota una figura de la Virgen, «maciça de gran peso", que se deshizo antes de 1539 para hacer una nueva «de mayor altura e tiene un niño lesu desnudo con una paxarilla de plata en la mano e tiene una corona e está sobre un pie que tiene las armas de los Manriques con doze esmaltes e cada uno una figura de apóstol». Otra de Santiago, también de plata sobredorada y de gran peso, donada -quizá como la anterior por el arzobispo Gómez Manrique (1362-1375), que igualmente fue renovada antes de 1539 para hacer otra mayor del mismo santo, con su «capelo negro e una benerica e un votoncico dorado y en la mano derecha un bordón con un escudete de las armas de Manrriques e en la otra mano un libro de plata en que está escripto qui conceptus est ecétera e por el ombro una cinta; tiene la peana ocho másteles [sic] y ocho esmaltes con sus ymágenes e debaxo de la ropa a los pies dos pieças de cortapisas clavadas, esmaltadas». Se citan también dos imágenes pequeñas de la Virgen y de San Francisco, que fueron fundidas para hacer de ellas dos hacheros grandes. Y, por último, una

\footnotetext{
6 Torre, A. de la; Torre, E. A. de la:Cuentas... I, pág. 51; Idem, Cuentas... ll, pág. 39.

7 Prieto Cantero, A.:, Casa y descargos de los Reyes Católicos, Valladolid, 1969, págs. 544, 536 y 557, 547, 551, y Legajo 4, fol. 281

8 A.O.F.C.T. (s.c.): Inventario de alhajas del Sagrario 18 Junio 1539, fols. 4v, 6, 15-16v. Los mismos asientos constan en el Libro de la visita del Arzobispo don Gaspar de Quiroga a la Catedral de Toledo e Inventario de las alhajas contenidas en el Sagrario, 15 Junio-13 Agosto, 1580, fols. 9-9v
} 
imagen pequeña de Santa Catalina de Siena - la única que se conserva actualmente ${ }^{9}-$, fechada en el siglo xv, que fue comprada al monasterio de la Madre de Dios. En cuanto a los relicarios, la Catedral sólo poseía en 1535 dos que presentaran la imagen completa del santo: el de San Ildefonso y el de San Eugenio (actualmente en el Ochavo), donación ambos del arzobispo don Gil de Albornoz (1339-50).

La preferencia en utilizar como relicario la propia figura del santo ${ }^{10}$, en lugar de otras tipologías más o menos convencionales, forma parte, por otro lado, de las nuevas relaciones entre el fiel y la divinidad que la Iglesia intenta favorecer desde finales del siglo xiII La progresiva «humanización» de las imágenes religiosas que proliferan en el interior de los templos, fue uno de los medios más significativos y probablemente más influyente en las conciencias, pues la apariencia física de los personajes - cada vez más perfecta gracias al progreso artístico- y su actitud sin hieratismo las hace más próximas, más accesibles, sin que por ello pierdan dignidad. Por lo mismo, se insiste sobre todo en las figuras de los santos y de la Virgen, cuyo papel de intercesores ante Dios les convierte en protagonistas a menudo más importantes en la devoción particular. Estos aspectos, en fin, potencian o simplemente coinciden con una necesidad estética, que había palpitado en el arte europeo occidental desde la desaparición misma del Imperio romano, cual era la de recuperar de un lado la belleza y corrección de la figuración clásica y, de otro, matizar esa imagen ideal con aspectos inherentes al hombre -gestos, caracterización física, vestimenta, o el extremo del ilusionismo real de las calidades de las cosas- que gratifiquen al artista porque como creador representa el mundo al que pertenece, y al espectador porque las reconoce como algo cotidiano. El arte de la platería cuenta con ejemplos significativos a este respecto a lo largo de toda la etapa medieval. Algunos de ellos muestran incluso un estado de evolución más avanzado que el de las artes plásticas coetáneas, si bien en la época tardía a la que pertenecen las piezas que estamos comentando la dependencia de los prototipos de la escultura y la pintura resulta ya inevitable (hasta tal punto que será frecuente a partir del siglo xvI la participación de artistas plásticos en los modelos de obras de platería). El detalle mismo de utilizar pigmentos para dar una apariencia verosímil a las carnaciones visibles de las figuras, como se hace por ejemplo en las figuras de San Sebastián y de la Virgen que aquí estudiamos, es -por encima del afán realista

\footnotetext{
9 En el inventario de 1539 (fol. 15v), consta expresamente que esta imagen de Santa Catalina se había comprado por orden del canónigo obrero don Diego López de Ayala, es decir, dentro del primer tercio del siglo xvi. Por otra parte, debemos señalar que la identidad de la Santa ha sido objeto de confusión, quizá por no haber conservado más atributo iconográfico que una palma de martirio. Así, M. Revuelta Tubino y otros: Inventario artístico de Toledo. Catedral Primada, Madrid, 1989, I, pág. 176, figs. 51 y 11, pág. 266, la identifican indistintamente como Santa Inés o, con dudas, como Santa Leocadia. Aluden también a que «en inventarios antiguos se dice ser Santa Elena, y las reliquias de Santa Inés, Santa Águeda y Santa Bárbara». ignoramos de dónde procede este dato, pues al menos en los inventarios del Sagrario que corresponden al siglo Xvi no se recoge en absoluto esta circunstancia. Los mismos autores se equivocan también al considerar que la pieza es "de madera forrada de plata".

10 Conocemos la existencia de piezas similares - todas ellas relicario y realizadas en el siglo xv- en otros centros religiosos del área castellana: el convento de Santo Domingo el Real de Toledo, por ejemplo, tiene una imagen del Santo titular, que según el cronista de la orden había mandado hacer Maria Zeledón, "religiosa que fue del coro" (cfr. Martínez Caviró, B.: Conventos de Toledo, Madrid, 1990, pág. 130). La catedral de Santiago de Compostela posee imágenes de la Virgen con el Niño, Santiago Apóstol, San Francisco de Asís, Santo Domingo, San Pedro, San Juan Bautista y San Andrés. $\mathrm{Al}$ parecer formaban parte de un conjunto total de diez figuras del oratorio de don Lope de Mendoza, al que se unían otras tres desaparecidas del oratorio del arzobispo Luna. Todas ellas estaban reservadas "para solempnizar et ornar a dita sua iglesia et para o altar mayor do dito santo apostolo", para lo cual eran colocadas en la "pirámide" de un baldaquino. Ademas de éstas, se conservan también otras dos imágenes de Santiago peregrino. Entre todas las citadas, al menos dos son de origen parisino, y las demás están realizadas por plateros italianos o flamencos afincados en Santiago (cfr. VV.AA.: Galicia no tempo, catálogo de la exposición en el Monasterio de San Martiño Pinario, Santiago de Compostela 1991, págs. 221 -226). También la catedral de Burgos posee imágenes de Santiago, San Pedro y San Pablo, en este caso probable obra burgalesa anterior a 1487 (cfr. Maldonado Nieto, M. T.: La platería burgalesa. Plata y Plateros en la Catedral de Burgos, Madrid, 1994, págs. 209-212, y Cruz Valdovinos, J. M.: Introducción a la platería de la Catedral de Burgos, en Tesoros de la Catedral de Burgos, catálogo de la exposición en las salas del Banco Bilbao Vizcaya, Madrid, 1995, págs. 109-113).
} 
propio del momento- una imitación de los recursos del mismo tipo utilizados en las tallas de madera. Por otra parte, el efecto de trabajar con un nuevo concepto retratístico a la hora de definir la fisonomía de cada personaje, resulta aún más llamativo cuando las figuras se reúnen en un conjunto, ya que cada imagen puede ser perfectamente identificada, no sólo por los instrumentos que la acompañan y que actúan como símbolos parlantes, sino también por sus características físicas. Si añadimos a esto la posibilidad que ofrecen otros formatos de relicarios para representar al personaje de cuerpo entero, de busto o simplemente su cabeza ${ }^{11}$-superando así el primer paso dado a mediados del siglo xI por los relicarios que reproducen sólo formas anatómicas-, y la costumbre de exponerlos todos juntos en un lugar común, el resultado viene a tener a veces paralelismos muy claros con las galerías de retratos de familia o, mejor aún, de personajes ilustres, que se reunen en las residencias principescas a partir del mismo siglo xv.

Finalmente, el uso de materiales preciosos en la configuración de este tipo de imágenes, responde no sólo a la dignidad de los ámbitos privilegiados en los que éstas cumplen su función, sino también a un creciente sentimiento de lujo y riqueza ilustrativos del poder de la persona o institución que los posee. Todo ello podría relacionarse con el proceso de sedentarización de las cortes principescas y el nacimiento de un coleccionismo moderno que se inician en el mismo siglo xv. Pero es probable también que en el caso que nos ocupa, por el sentido religioso de las imágenes, aún se haya considerado la antigua idea medieval que interpretaba el esplendor y la riqueza sensorial de los materiales como un reflejo de la propia divinidad.

\section{Las imágenes vendidas por doña Mencia a la Catedral de Toledo}

Las imágenes contenidas en la testamentaria de la reina Isabel habían sido adquiridas por los compradores en todos los casos sólo por el valor del material (algunas llevaban incluida una funda de lienzo y una caja de cuero negra para guardarlas). Se anota de todas formas el valor en que fue estimada su hechura por los plateros reales que actuaron como tasadores: Diego de Ayala, Hernando (o Fernando) de Ballesteros y Pedro Fernández (o Hernández) de Córdoba. El precio resultó ser inferior -excepto en la imagen de San Antonio- a los 1.000 mrs. que, como hemos visto, se habían tomado como baremo para algunas de las imágenes realizadas por encargo de la Reina en 1489 y 1492: el precio mínimo de hechura fue ahora de 500 mrs., aunque la mayoría de las imágenes se tasaron en $600 \mathrm{mrs}$. y sólo una en $750 \mathrm{mrs}$. El Conde de Ureña pagó por las doce que había comprado un total de $623.242 \mathrm{mrs}$., lo que da un precio medio por ima-

\footnotetext{
11 La catedral de Toledo tenía en 1535 un "medio cuerpo" de San Juan Bautista (sustituido en 1585 por el que hay se conserva, realizado por Diego de Valdivieso), uno de San Mauricio y compañeros, y otro de San Sebastián (obra de Diego Vázquez y Pedro de Medina en 1514). Una "cabeza» de San Leandro (desaparecida ya en 1539), otra de San Germán y la de un mártir compañero de San Mauricio, desaparecidas ambas antes de 1580 (cfr. A.O.F.C.T. (s.c.): Inventario... 1539, fols. 2v, 5v, 6, 9). Posteriormente, la Catedral recibió en donación otra imagen relicario de Santa Mónica -hoy en el Museo-, datada también el siglo xv; la pieza había sido regalada en origen por el papa Urbano VIII a don Pedro de Losada, capiscol y canónigo cuyos herederos la dieron al cardenal Moscoso en 1662 (Cfr. Revuelta Tubino, M.: Inventario..., pág. 268).

Queremos aprovechar la oportunidad para hacer algunas precisiones respecto al busto relicario de San Mauricio, pues presenta algunos problemas de identificación por haber contenido durante un tiempo las reliquias de San Sebastián y San Fabián, y llevar actualmente un nimbo en el que se lee el nombre de San Juan. Al parecer, sólo se trataba al principio de una cabeza de plata con reliquias en su interior, donada por el rey Fernando I de Aragón (+1416), y no por Fernando el Católico como han considerado algunos autores (cfr. Yarza Luaces, J.: Los Reyes Católicos. Paisaje artístico de una monarquía, Madrid, 1993, pág. 320). La cabeza va unida a unos hombros, también de plata, donde aparecen los escudos de la familia Luna y el escudo papal de Benedicto XIII (1394-1423), además de una inscripción en la que consta el nombre de don Pedro de Luna, arzobispo de Toledo (1404-1414). El cuerpo es de madera y lleva un chapado en plata que debió ser realizado a comienzos del siglo xvi por Diego Vázquez y Pedro de Medina; en cuanto al nimbo con el nombre de San Juan, lo más probable es que esté aprovechado de otra pieza que representara a este santo.
} 
gen de 51.937 mrs. Cuando años después su viuda vendió diez de ellas -más la de Santiago el Menor- a la Catedral de Toledo, el precio (incluidos material y hechura) fue de 8 ducados y medio (3.187 mrs. y medio) por marco, salvo en el caso de la imagen de Santiago el Mayor que se redujo a 2.872 mrs. y medio por marco. Su valoración quedaba así por encima del precio estimado para las otras piezas vendidas por doña Mencía: los blandones se pagaron a $2.656 \mathrm{mrs}$./ marco, la naveta a $2.500 \mathrm{mrs}$./marco, y el acetre a 7 ducados $(2.625 \mathrm{mrs}$. $) /$ marco. El precio medio por imagen habría sido pues de $69.987 \mathrm{mrs}$. El peso de cada una estaba entre 20 y 16 marcos (4.660 y 3.680 g.), con dos excepciones: la de Santiago el Mayor, que pesaba más de 26 marcos (5.980 g.), y la de la Virgen que apenas llegaba en cambio a los 11 marcos (2.530 g.). Todas ellas iban sobredoradas, pero sólo consta que la imagen de San Sebastián llevara «el cuerpo e piernas pintado de encarnaçion». Por lo que se desprende de las descripciones contenidas en los documentos de la Catedral de Toledo, parece que en el estado de conservación de las figuras se advertían ciertas faltas y deterioros, señalándose en particular la pérdida en algunos casos de los escudos dispuestos en las peanas, aunque no era lo único. Ya en la almoneda de la Reina constaba que a la imagen de San Andrés adquirida por el Conde le faltaban los dedos pulgares de ambas manos, pero debieron componérselos pues no se anota esta incidencia cuando se vendió a la Catedral. Siendo ya propiedad de ésta y tan sólo unos meses después de su adquisición, constan los pagos correspondientes a los reparos que fue necesario realizar en casi todas las imágenes. El primero, en 29 de mayo de 1536, se libró al platero de Toledo Pedro Ramírez por la plata, oro y hechura que empleó principalmente en renovar nimbos -como "diadema» se refieren a ellos- y atributos iconográficos, además de adobar y limpiar cada una de las imágenes: a la Virgen se le hizo una azucena, a San Pedro una llave -ya en la testamentaria consta que sostenía "el cabo» de una llave, lo que puede ser indicio quizá de que había perdido el resto-, un libro y una diadema; a San Sebastián, tres saetas; a San Juan Evangelista, un cáliz «con dos syerpes» y la diadema; a San Felipe, un libro; a San Juan Bautista, una diadema. Sin especificar, se citan otras tres imágenes que tan sólo se adobaron y limpiaron, debiendo dorarse la diadema de una de ellas: han de ser las de San Pablo y los dos Santiagos. De plata fueron 5.234 mrs., del oro para los sobredorados $1.070 \mathrm{mrs}$., y de las hechuras $2.404 \mathrm{mrs}$. ${ }^{12}$. Posteriormente, el 1 de junio de 1536, el pintor Francisco de Comontes percibía 1.000 mrs. «por encarnar los rostros de la ymágenes de plata que compraron para el Sagrario»" ${ }^{13}$.

Como hemos visto por la enumeración anterior, cada figura llevaba los atributos iconográficos que le eran propios. En este sentido, la testamentaría y los inventarios de 1539 y 1580 de la Catedral de Toledo - en el segundo se revisan los datos de los inventarios precedentes y se vuelven a pesar incluso algunas piezas, corrigiendo los errores que hubiera al respecto-, nos proporcionan más noticias: la imagen de San Juan Bautista sostenía un cordero en una de sus manos; Santiago el Mayor, llevaba bordón, sombrero - con el cordón de plata en su color- y una bolsa; San Andrés, un aspa; San Felipe, una lanza; San Bartolomé, un libro y dos cuchillos; Santiago el Menor, una porra larga ${ }^{14} \mathrm{y}$ un "vecte salonis», pero, además, su peana era la única que tenía "sobrepeana" y no llevaba escudos. Estos últimos, sí se encontraban, en cambio, en las diez imágenes procedentes de la cámara de la reina Isabel. Su análisis permite concluir que las piezas se hicieron en momentos diferentes del siglo xv, e incluso que algunas de ellas procedían de herencia

12 A.O.F.C.T. [830]: Libro de Frutos y Gastos. 1536, fol. 65v.

13 Ibídem, fol. 77. Esta noticia fue publicada por Zarco del Valle, M. R,: Documentos de la Catedral de Toledo, en «Datos Documentales para la Historia del Arte Español», Madrid, 1916, I, pág. 198.

${ }^{14}$ Hay una cierta confusión con las imágenes de San Felipe y Santiago el Menor (recordemos que esta ultima no procedía de la almoneda real). En la testamentaria de la Reina se dice que la imagen de San Felipe llevaba una "porra larga". En la partida de la venta a la Catedral de Toledo se identifica como San Mateo, mientras en el inventario de 1539 se describe ya la imagen de Santiago con una porra y la de San Felipe con una lanza. La lanza no es, sin embargo, el signo iconográfico de este santo sino el del apóstol Santo Tomás, siendo el de San Felipe una cruz. 
familiar. Por otra parte, el orden en que estas imágenes se citan en la testamentaria real puede corresponderse con los distintos grupos que formaban, pues se relacionan consecutivamente las piezas que coinciden en el escudo y en la forma en que éste iba dispuesto en la peana:

1. La imagen de la Virgen tiene, según los documentos, las armas de Castilla-León y Aragón "con sus calderas alderedor»; como las imágenes de San Jerónimo, San Andrés y probablemente también la de Santo Domingo, compradas por Luis López en la almoneda real. El escudo pertenece a don Fernando de Antequera (+1416), infante de Castilla y rey de Aragón, de quien debieron heredarlas los Reyes Católicos, pues era abuelo de don Fernando y tío abuelo de doña Isabel. Las calderas hacen alusión al señorío de Lara que se contaba entre sus posesiones desde 1390 15; al no ir timbrado el escudo con corona es probable que la pieza pueda fecharse antes de su acceso al trono de Aragón, en la época en que desempeñó la regencia del reino de Castilla (1406-1412).

2. La imagen de San Juan Bautista llevaba las armas reales de Castilla y Aragón. Suponemos que no serían sólo las armas de Castilla, sino las de Castilla y León. Teniendo en cuenta esto, podría tratarse del escudo de doña María de Aragón (+1447), primera esposa de Juan II de Castilla, quien usaba un cuartelado de Castilla y León y Aragón. O bien de don Fernando el Católico, pues utilizaba antes de su casamiento con doña Isabel en 1469 un escudo cuartelado de Aragón, Castilla y León.

3. San Juan evangelista, Santiago el Mayor, San Pedro y San Andrés, llevaban las armas reales de Castilla y León. La interpretación del escudo sólo con este dato admitiría tres posibilidades: podría corresponder a la época de Juan II (+1454) o de Enrique IV de Castilla (+1474), padre y hermanastro, respectivamente, de Isabel la Católica, o bien pertenecer a ésta última, pues se conoce un sello suyo fechado en 1473, en el que aparecen las armas de Castilla y León aunque sobre el águila de San Juan, motivo que no se menciona desde luego en las imágenes que comentamos.

4. Las de San Sebastián, San Pablo, San Bartolomé y San Felipe -como las de San Jerónimo y San Lucas compradas por Pizarro en la almoneda y quizá también la de San Antonio de Luis López- llevaban, según la testamentaría, las armas reales con las divisas del yugo y las flechas. Sólo en la de San Jerónimo se dice "sin la granada" y "con unos rrotulos de las letras de tanto monta». Si esto último puede hacerse extensivo a las demás imágenes, estarían realizadas todas ellas entre 1479 y 1492. No obstante, procederían de encargos distintos, por las diferencias que se anotan en la disposición y el número de los escudos: San Sebastián y San Jerónimo, tenían dos escudos y las divisas; San Felipe y San Lucas llevaban seis esmaltes que contenían los escudos y las divisas; San Pablo y San Bartolomé tenían cuatro esmaltes redondos, «los dos de las armas rreales y los otros dos de las flechas» (en el inventario de la Catedral de 1539 se mencionan también los yugos).

Centrándonos ya en las cuatro imágenes conservadas en la Catedral de Toledo, debemos señalar que su existencia ha sido mencionada con anterioridad por otros autores, aunque en algunos casos se han producido distintos errores de apreciación que conviene revisar ${ }^{16}$. Por ejemplo, ninguna de ellas ni de las otras que formaban el conjunto vendido por doña Mencía de

15 Para éste y otros datos sobre la interpretación de los escudos que aparecen en las piezas cfr. Menéndez Pidal de Navascués, F.: Heráldica medieval española, I. La Casa Real de León y Castilla, Madrid, 1982, págs. 180-201.

16 Conde de Cedillo: Catálogo Monumental y Artístico de la Catedral de Toledo, Madrid, 1919; ed. de M. Revuelta Tubino, Toledo, 1991, págs. 106, 108, 126. González Simancas, M.: Toledo, sus monumentos y el arte ornamental, Madrid, 1929, págs. 123-124, 142-143. Rivera, J. F.: La cathédrale de Tolède, Barcelona, 1957, págs. 38, 39; figs. 74, 79. Revuelta Tubino, M. y otros: Inventario..., I, págs. 193, 308, figs. 53, 107, y 11, págs. 145, 303, 315-316 fig. 260. VV.AA., Piedras vivas. La Catedral de Toledo 1492, catálogo de la exposición del mismo título en la Catedral de Toledo, Toledo, 1992, págs. 117 y 120. 
Guzmán, albergaban reliquias. Sin embargo, González Simancas incluye las de San Sebastián, San Pedro y San Pablo en el apartado de relicarios, quizá sólo porque su emplazamiento habitual ha estado en el Ochavo, donde las localizan también el Conde de Cedillo y los autores de Inventario artístico (en la tercera ochava empezando por la derecha); Casamar, en cambio, las sitúa en el Tesoro. aquí se en contrarían también según este autor la de San Sebastián y la de la Virgen con el Niño, si bien en el Inventario se cataloga la imagen de la Virgen en la sala I del Museo catedralicio, donde efectivamente pudimos verla nosotros antes de 1992. Respecto a la noticia de la compra de estas imágenes a doña Mencía de Guzmán, sólo se refieren a ello González Simancas -que cita como fuente el inventario de 1539- y J. F. Rivera, pero ambos se equivocan en identificar a la dama con doña Mencía Enríquez, esposa del Duque de Alburquerque. La datación de las piezas también ha sido objeto de opiniones más o menos afortunadas: González Simancas fecha la imagen de San Pablo en el siglo xiv, pues dice -lo que no es cierto- que lleva grabado en el libro que sostiene el escudo del arzobispo Albornoz. En cambio, considera que la de San Pedro es del siglo xv, por la decoración del galón del manto, mientras la de San Sebastián sería «algo más moderna", y añade: «sus caracteres artísticos proclaman que se labró en Italia», apostando incluso por un origen florentino. Rivera, en cambio, la califica de "gótica", no cita las de San Pedro y San Pablo y equivoca la interpretación del escudo de la peana de la Virgen, pues se refiere a ella como una imagen "del siglo xv con blasón de los Reyes Católicos y calderos de los Manrique». Por su parte, el Conde de Cedillo considera el San Pablo como «obra no muy fina» dentro de un "arte gótico decadente posterior a 1500 », señalando que la espada es típica del siglo XVI, fecha en la que debe situar también erróneamente la peana, pues al referirse a ella menciona "labores del Renacimiento». Este último comentario y la cronología de la imagen se hacen extensivas a la de San Pedro, mientras la Virgen con el Niño se fecha a mediados del siglo xvi; no cita la imagen de San Sebastián. En el Inventario artístico se fecha la Virgen a mediados del siglo xv, el San Pedro se caracteriza como obra de «arte hispano-flamenco de finales del siglo XV", y el San Pablo se sitúa dentro de un estilo «más gótico y expresivo», comparando los plegados de su vestimenta con los de las esculturas de la Puerta de los Leones de la Catedral toledana; en cuanto al San Sebastín consideran que su estilo «recuerda a los Egas» y se equivocan con la posibilidad de identificar esta imagen con el busto relicario de San Juan Bautista, realizado en 1514 por Diego Vázquez y Pedro de Medina. Casamar la caracteriza con acierto como obra del siglo xv anterior a 1492, observando su relación -que no es exacta de todas maneras-, "por la basa y el escudo de los reyes», con la imagen de la Virgen con el Niño; fecha el San Pedro y el San Pablo en el siglo xv y describe las tres con detalle, pero sin pronunciarse sobre su posible origen de realización ni tener en cuenta el dato de la compra a doña Mencía. De hecho, aunque en la imagen de San Sebastián todos los autores citados constatan la presencia del escudo de los Reyes Católicos, en ningún caso se ha llegado a investigar sobre esta circunstancia.

Las características de estas piezas, según nuestro propio estudio, son las siguientes:

Las cuatro están realizadas en plata sobredorada al fuego, a excepción de la corona y el cetro que sostiene la Virgen y de las peanas de las figuras de San Pedro y San Pablo que son de plata en su color; las imágenes de San Sebastián y la Virgen llevan las carnaciones pintadas ${ }^{17}$, con pérdidas parciales en algunas zonas, como sucede con los esmaltes de los escudos, en color rojo, blanco y negro opacos. En el cuerpo de San Sebastián sólo se conserva una saeta, quedando manifiestos los orificios de otras siete que faltan; la imagen de San Pablo ha perdido la parte inferior de la espada, presenta grietas en el dorso, a la altura del cuello y en la base inferior del man-

17 También en este caso Revuelta, M. y otros: op. cit.., consideran erróneamente que las piezas son de madera forrada de plata, aunque en otro lugar del Inventario mencionan en cambio el material verdadero. 
to, se aprecian dos orificios en la cabeza y están dobladas y desgastadas las esquinas superiores de la peana; en la de San Pedro hay dos orificios sobre el manto a la altura de la mano que sostiene la llave, otro en la palma de la mano que lleva el libro, uno en el ojo izquierdo y dos a cada lado de la cabeza, aparecen también grietas en diversas zonas del manto, y muestra cuatro tornillos de sujeción propios de una reparación posterior; en la imagen de la Virgen se aprecia un corte completo a la altura de las muñecas, además de un orificio en la túnica del Niño. Las medidas de cada pieza son las siguientes: $48,3 \mathrm{~cm}$ y $46 \mathrm{~cm}$ de altura, respectivamente, de las figuras de San Pablo y San Pedro; la peana de ambas, $15,2 \times 16 \mathrm{~cm}$ de lado (cuatro); la imagen de la Virgen tiene $40,5 \mathrm{~cm}$ de altura y $11 \times 7,5 \mathrm{~cm}$ de lado (seis) en la pena; la de San Sebastián mide $62 \mathrm{~cm}$ de altura total, incluida la peana. Técnicamente, se ha combinado -como es habitual en este tipo de imágenes- la fundición con chapas conformadas, unidas entre sí por soldadura o mediante clavos y grapas que quedan ocultos y tornillos vistos. Los nimbos y las portadas de los libros se han trabajado combinando cincelado plano y grabado; las ojivas de los contrafuertes de la peana de San Sebastián están solo grabadas; las casetas de la peana de la Virgen y la cenefa de las ropas de San Pedro llevan labores de "picado»; los escudos están trabajados en placas independientes y llevan los motivos cincelados, con los esmaltes aplicados en champlevé. Las peanas de San Pedro y San Pablo presentan buriladas en cada una de las caras y en su parte interna; en la zona superior de ambas aparecen también las siguientes marcas: abreviatura del nombre de la ciudad de Toledo -inicial T con o sobre el travesaño vertical - coronada, sobre cronológica de dos cifras (97), en contorno rectangular; BIOSCA, apellido completo en una linea y dentro de contorno rectangular; XIMZ, apellido abreviado -la letra final aparece invertida- en una linea y dentro de contorno rectangular. Los nimbos de San Sebastián, San Pedro y San Pablo llevan inscripciones con sus respectivos nombres: SANT SEVASTIAN, SAN PEDRO, SANTE [soldadas las tres letras finales] PABLO. La peana de la Virgen lleva dos escudos iguales: medio cortado con castillo de gules y león rampante de sable, partido de bastones en gules sobre oro y bordura de plata con ocho calderos de sable. La peana de la imagen de San Sebastián lleva otros dos, también iguales: timbrado con corona real, cuartelado, el primer y cuarto cuartel con cuartelado de castillos sobre gules y leones de gules, el segundo y tercero partidos con cuartelados en aspa de bastones de gules sobre oro (en realidad el fondo va esmaltado en blanco) y águilas de sable; van flanqueados por las divisas del yugo y las flechas.

Las cuatro figuras son de cuerpo entero y bulto redondo, se presentan en posición frontal, aunque las piernas intentan un ligero desplazamiento que provoca la movilidad de los paños. La Virgen y San Pedro muestran una cierta idealización clásica, que las hace parecer algo frías frente a las figuras de San Pablo y San Sebastián, menos correctas en su modelado, pero a cambio mucho más expresivas.

Virgen con el Niño (¿1406/12?) (Figs. 1 y 2). Tiene paralelismos evidentes con la estatuaria gótica francesa, que además de los ejemplos diversos en marfil o en piedra, cuenta también con obras excepcionales en plata sobredorada como la Virgen relicario (Louvre) donada en 1339 por la reina Juana de Evreux a la iglesia de Saint-Denis, o la Virgen del tesoro de la Catedral de Mantua fechada en la segunda mitad del siglo XIV ${ }^{18}$. La imagen conservada en Toledo coincide con ellas en la nueva iconografía que potencia la relación afectiva entre la Madre y el Niño, para lo que se prefiere prescindir a menudo del trono al que ambas figuras estaban asociadas desde el principio. Gracias a ello, la Virgen se dispone en pie, forzando una serpentina en su figura, para sostener al Niño sobre el regazo, mientras lleva en la mano libre algún elemento asignado a su imagen. La nueva posición permite al Niño situarse a la altura del rostro materno y acariciarlo incluso con una de sus manos; la Madre se vuelve hacia él pero con la mirada perdida y triste,

18 VV.AA., Le trésor de Saint-Denis, catálogo de la exposición en el Museo del Louvre, París, 1991, págs. 246-254. 


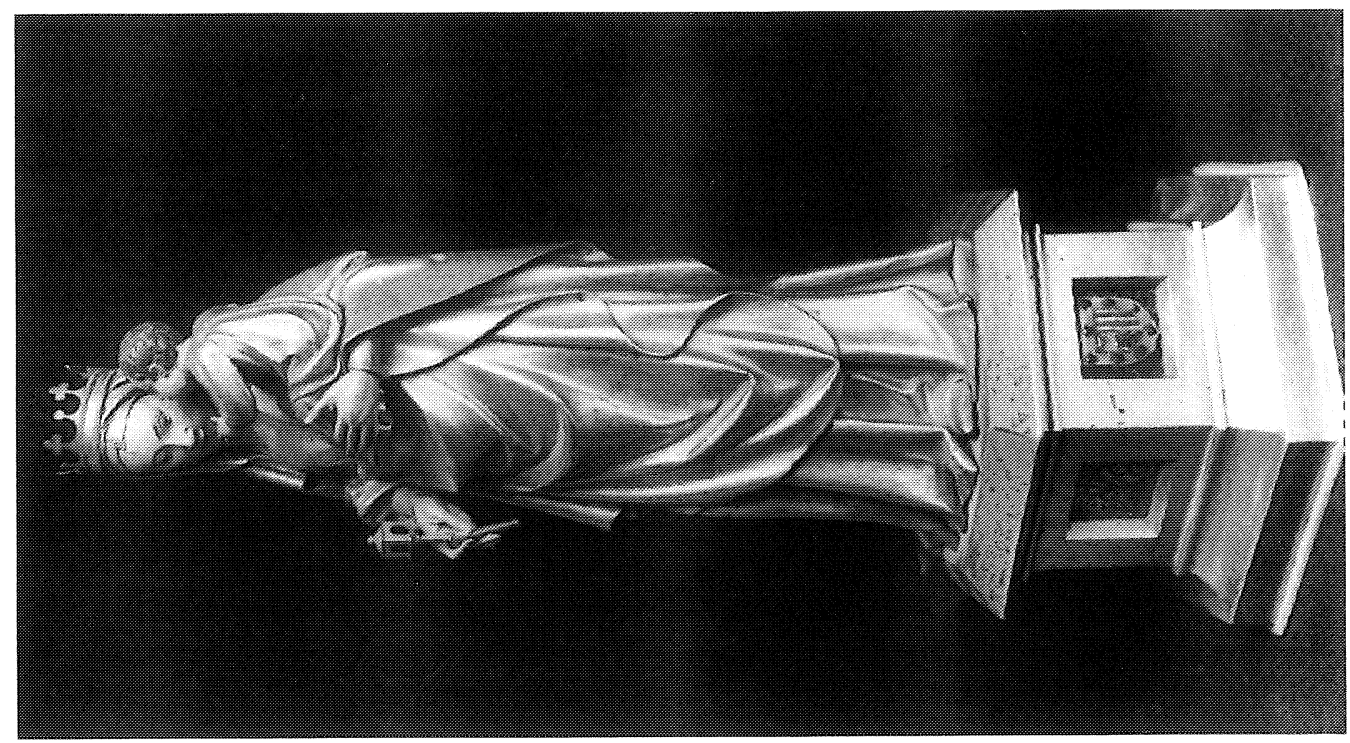

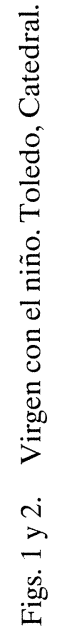

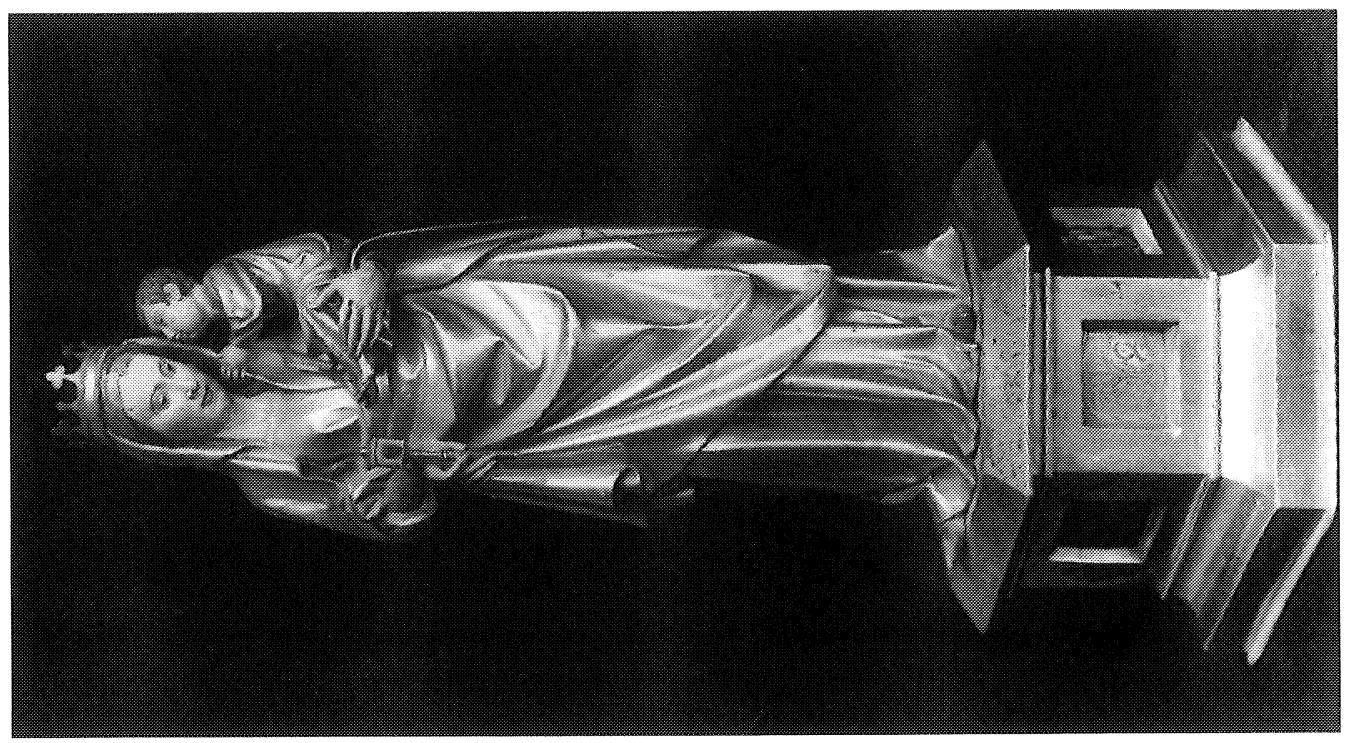


como es característico en las vírgenes melancólicas bajomedievales. Como suele suceder también en éstas, la imagen de Toledo va ataviada convencionalmente con una saya sencilla que deja asomar los pies calzados, y un manto que queda recogido sobre el cuerpo con pliegues amplios y angulosos, además de ir tocada con corona real; lleva también aquí un velo con pliegue central que cae sobre la frente, al tiempo que asoma el cabello largo en algunas zonas; su rostro es ovalado con rasgos bien perfilados, a lo que ayudan los pigmentos utilizados. El Niño va vestido con una túnica de superficie matizada que simula un tejido diferente; el cabello es corto y está trabajado con detalle, su mano no llega a alcanzar el rostro de la Virgen y la mirada se pierde también en otra dirección Por otra parte, ya hemos visto que cuando la Catedral compró esta imagen se le hizo a la Virgen una azucena, que más tarde -quizá en el siglo xvII- debió sustituirse por el cetro con cabeza a modo de templete que lleva ahora. Es posible que entonces se rehicieran también ambas manos, a juzgar por su modelado y sobre todo por los cortes que aparecen a la altura de las muñecas, además del orificio visible en la figura del Niño que no se corresponde con la posición de la mano de la Virgen. La peana sobre la que asienta esta imagen es de planta exagonal, con zócalo y cornisa salientes, y casetas abiertas en el cuerpo, ocupadas en alternancia por motivos vegetales simetrizados trabajados en labor de "picado", y escudos que, como hemos visto, pertenecen al infante de Castilla don Fernando de Antequera.

San Pedro (tercer cuarto del siglo xv) (Figs. 3 y 5). Va ataviado con túnica larga, bajo la que asoman los pies descalzos, lleva también capa con capilla abrochada en el cuello y recogida sobre el cuerpo de forma semejante a la imagen de la Virgen; el bajo de la túnica y todo el contorno de la capa llevan grabados en labor de "picado» lo que parecen ser las letras de una inscripción ${ }^{19}$. Sostiene en las manos una gran llave y un libro; este último muestra un único cierre y una encuadernación con cenefa romboidal y tallo vegetal en el centro. Ambos elementos se deben -como sabemos- a las composturas realizadas por Pedro Ramírez en 1536; los orificios que se aprecian en torno a esta zona deben corresponder a la situación y forma de sujeción de los instrumentos originales. También el nimbo se renovó entonces, adoptando la forma de un disco muy amplio casi completo, que contiene un cerco de rayos y la inscripción con el nombre del santo - con las dos palabras separadas por puntos-, cincelados en liso sobre fondo matizado; su base, de perfil trilobulado, no encaja exactamente sobre la cabeza del santo, probablemente por haber variado su posición inicial, lo que explicaría también los orificios que se observan a ambos lados de la cabeza. No obstante, la cabeza misma se encuentra desprendida del cuello, por lo que fue necesario asegurarla con tornillos y no con soldadura, quizá porque la pieza se habría deformado con el calor. Tenemos noticia de esta incidencia gracias al inventario realizado durante la visita arzobispal de 1580: en él se manda expresamente «que se ponga y afixe la cabeça que se anda». Si se hizo inmediatamente, es posible que se encargara de la compostura Diego de Valdivieso, pues ocupaba entonces el cargo de platero de la Catedral. Otros autores, como González Simancas y Casamar, opinan sin embargo que la cabeza de San Pedro no es la original. El segundo piensa que «es de muy buen arte y algo posterior» al resto de la figura. Pero González Simancas afirma ademas que no sólo la cabeza sino también las manos, el libro y la llave se hicieron nuevos en el siglo XVII. Por nuestra parte, no hemos encontrado en los documentos de la Obra y Fábrica de la Catedral ninguna nota referida a la posible renovación de la cabeza original, aunque también es cierto que no siempre se detalla el pormenor de los reparos que se realizan. Es, en todo caso, la de mayor calidad entre las cuatro imágenes que estudiamos y parece de hecho más avanzada en la forma del modelado o el tratamiento del pelo, pero no nos abrevemos a afir-

${ }_{19}$ Revuelta, M. y otros: op. cit., han transcrito: IN ADJV/TORI/DOMINV/MIC y ET/ADIVTOR / EDUC/U: CIMEI /O. González Simancas, en cambio - y Casamar opina lo mismo-, considera que se trata de "caracteres caprichosos que nada expresan, a pesar de tener cierta semejanza con las letras góticas». 

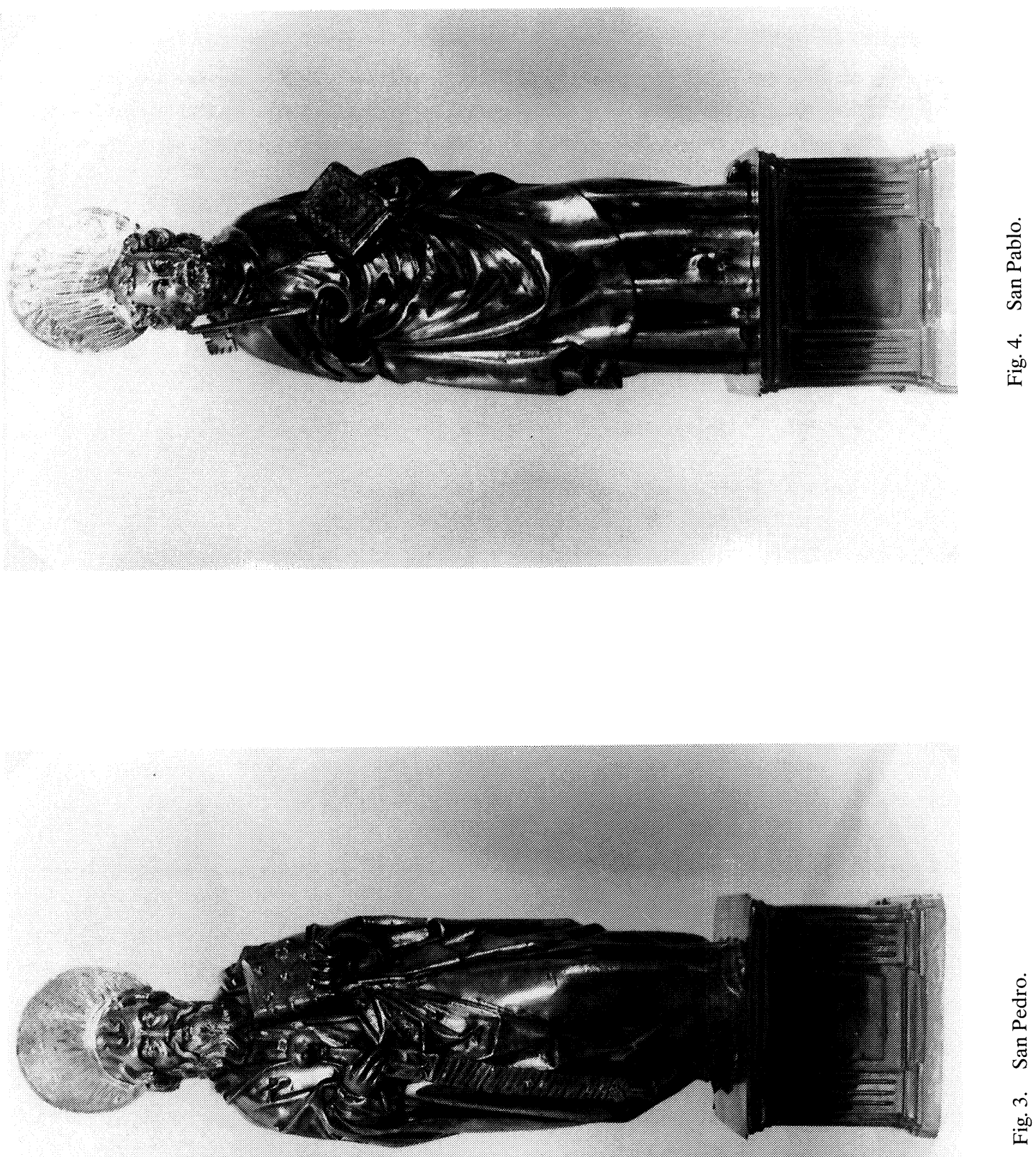


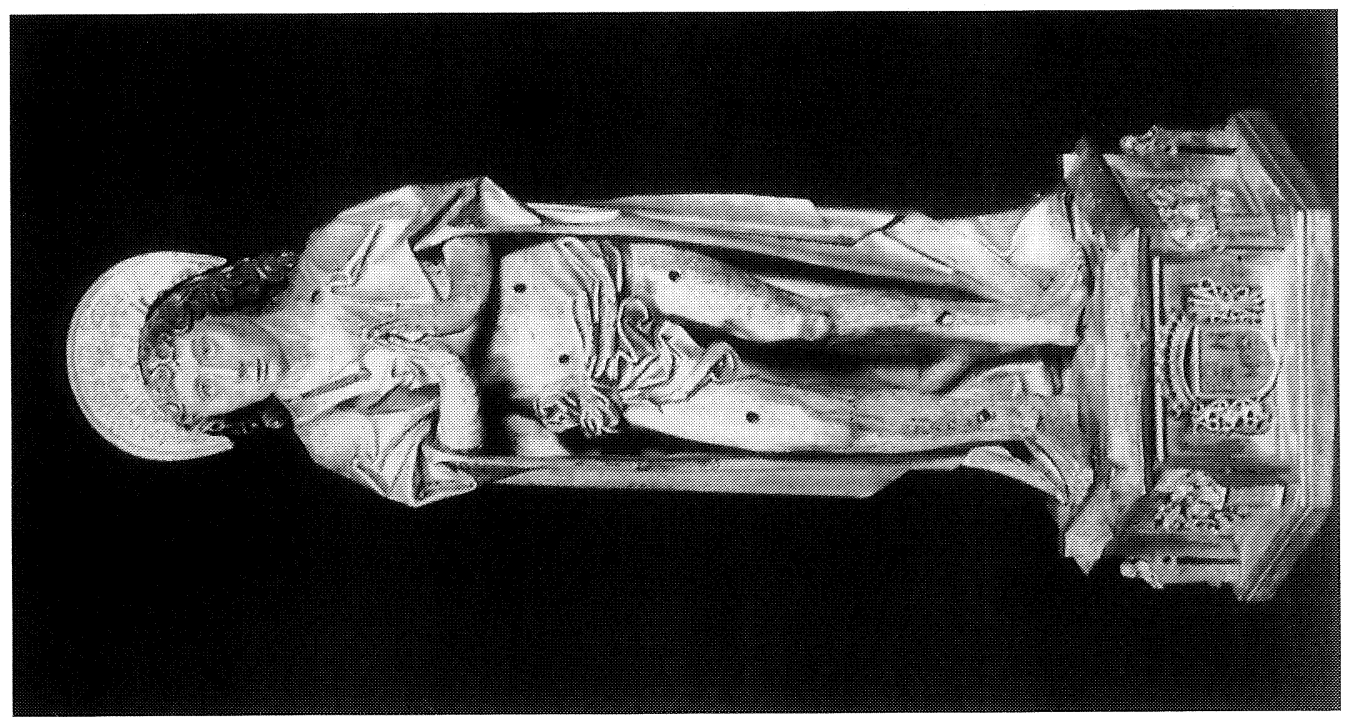

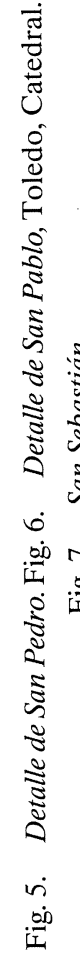
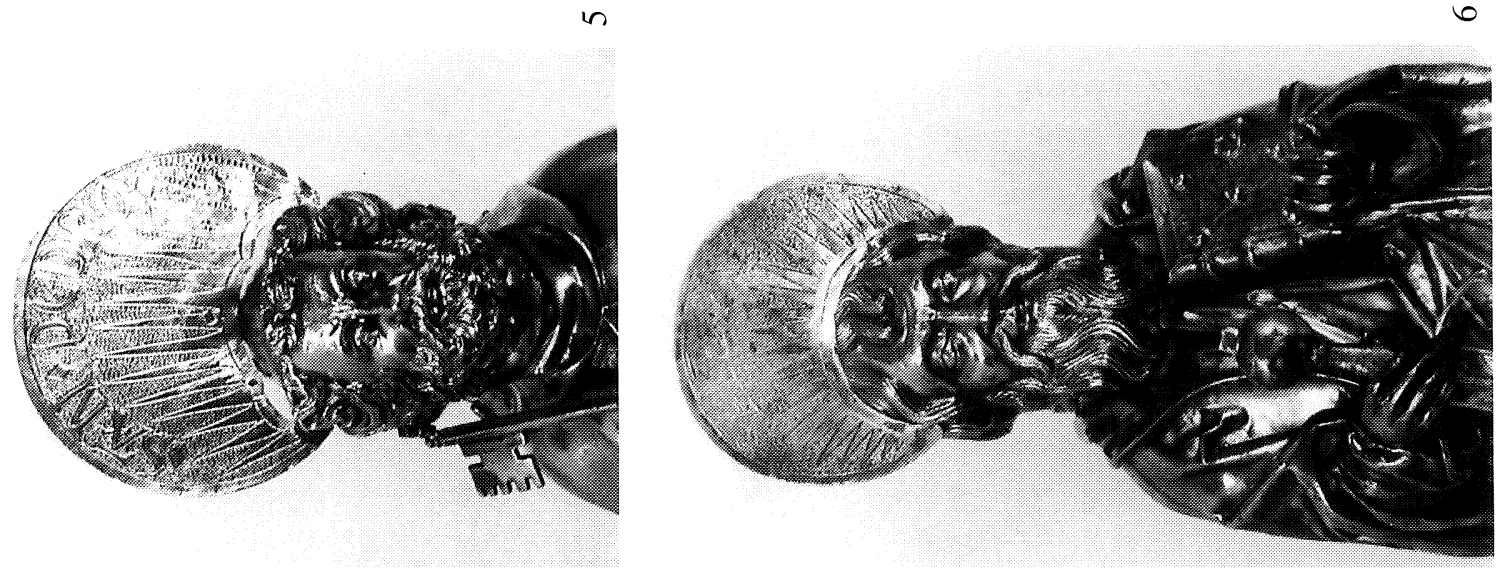
mar que no sea la cabeza original, pues su estado de conservación parece indicar que tan sólo se limitaron a asegurar su unión al cuerpo y nada más: los cabellos y la barba son abundantes y rizados, aunque va tonsurado; tiene un gesto severo que se refleja en el ceño fruncido, las arrugas ligeramente marcadas sobre la frente y los ojos -éstos últimos con las pupilas marcadas-, y los labios carnosos y apretados. De la peana original sólo sabemos que llevaba dos escudos de Castilla y León, uno en la parte frontal y otro en la trasera; este último, según el inventario de 1539 debía haberse perdido, pues se anota: «falta en la peana de las espaldas el redondo [tondo]»; en el inventario de 1580 se menciona también la falta del escudo "de delante». Finalmente, en el siglo XVIII se decidió renovar esta parte de la pieza: las marcas que aparecen en la peana actual indican su realización en Toledo, en 1797/1803 ${ }^{20}$, por Manuel Ximénez, platero de la Catedral. Su estructura y decoración se atienen a la sobriedad que caracteriza la platería neoclásica española del último cuarto del siglo xviII: es un cubo de caras cajeadas, con zócalo y cornisa salientes, en cuyos vértices confluyen pilastras escalonadas con acanaladuras en el fuste.

San Pablo (1479/92) (Figs. 4 y 6). Va vestido con túnica y manto abierto, también con los pies descalzos. Avanza con decisión una de las piernas, pero el efecto queda un tanto cortado por la simplicidad y acartonamiento de los plegados que le hacen parecer un tanto rígido. Sin embargo, la intención del artífice vuelve a manifestarse en la viveza de la expresión del rostro, con grandes ojos - también va marcada la pupila- y el ceño fruncido, aunque si se compara con la de San Pedro, se hacen evidentes su modelado más sumario y el linealismo en el tratamiento de los cabellos del pelo y la barba, más larga ésta y partida en dos. Las manos tienen menos volumen y -como advierte Casamar- los dedos de la que sostiene el libro casi parecen garfios. El libro muestra un solo cierre y simula un tipo de encuadernación que parece inspirada en las contemporáneas de cordobán con hierros estampados, nervios en el lomo y cinco chatones gruesos de metal ${ }^{21}$. En la otra mano sostiene la espada, enfundada en una vaina formada por una cinta que se enrolla en torno a la hoja. El nimbo es similar al de San Pedro, aunque el borde inferior en este caso es continuo, no hay puntos de separación entre las letras de la inscripción y una parte de ellas se presentan soldadas; estos pequeños detalles quizá indiquen que no se hicieran a la vez, o simplemente que no se renovara el de San Pablo, pues de hecho no se cita expresamente en la cuenta con Pedro Ramírez de 1536 que se hiciera un nimbo nuevo para esta imagen. La peana, en cambio, es idéntica a la de San Pedro pues fue realizada en las mismas fechas y por el mismo platero, como atestiguan las marcas que en ella aparecen. La peana original, según la descripción de la testamentaria real, tenía "4 esmaltes rredondos, los dos de las armas rreales y los otros dos de las flechas" y «unas trampicas de palo en el suelo». En el inventario de 1539 consta que eran "las armas de los Reyes Católicos y devisa de las ferchas [sic] e yugo"; aún permanecía sin cambios según el inventario de 1580. No consta, en cambio, el contenido exacto del escudo, aunque al citarse esta imagen dentro de la testamentaria real a continuación de otras dos que no llevaban incluida en él el emblema de la granada, hemos supuesto que podría estar realizada antes de 1492, y ser, quizá, una de las imágenes de apóstoles que se hacían para la Reina en 1489.

San Sebastián (¿1489? (Fig. 7). Esta imagen es buen ejemplo de la dificultad que podía suponer todavía para algunos artistas en esta época el hecho de tener que afrontar el modelado de una figura desnuda, sobre todo si se trataba de una imagen religiosa. Sea por una cierta inseguri-

20 La cronológica correspondiente al año 1797 que aparece unida a la marca de localidad, fue utilizada con carácter fijo por el marcador de Toledo, Pedro Biosca - a quien pertenece una de las dos marcas personales-, hasta 1804, de ahí que hayamos datado las peanas teniendo en cuenta este margen de tiempo.

21 Véase como ejemplo la encuadernación de las Actas de la Orden de Santiago (1480) conservadas en el Archivo Histórico Nacional de Madrid (Códice 900B), cfr. VV.AA.: Reyes y Mecenas. Los Reyes Católicos-Maximiliano I y los inicios de la Casa de Austria en España, catálogo de la exposición del mismo titulo en el Museo de Santa Cruz de Toledo, Toledo, 1992, pág. 304, n. 34. 
dad del autor, o quizá simplemente por decoro, el cuerpo de San Sebastián aparece enmarcado por un manto que cae desde los hombros, con pliegues amplios y algo planos; en torno a las caderas lleva anudado un reducido paño de pureza de pliegues acanalados, uno de cuyos extremos se prolonga convenientemente entre las piernas. La figura describe una serpentina ondulante que introduce cierta sensación de inestabilidad, además de la incorrecta posición del hombro que se adelanta al juntar levemente las manos en oración, o del giro en el pie de la pierna contraria. El cuerpo estaba herido por ocho saetas - ahora sólo queda una en el pecho-, distribuidas de dos en dos en el pecho, el vientre y las piernas. El modelado de la anatomía es muy suave, con apenas otro detalle que el de la marcada articulación de las rodillas; en cambio los rasgos del rostro están muy perfilados, lo que le hace aparentar esquematismo, no exento sin embargo de cierta expresividad, aunque sólo sea por el detalle de la boca ligeramente entreabierta. El cabello es largo y rizado; el nimbo es el original: tiene forma de media luna, y está trabajado de manera semejante a los que se hicieron para San Pedro y San Pablo en el siglo xvi, salvo porque lleva una cenefa dentada en el contorno y el nombre del santo flanqueado por roleos grabados. La peana responde a un modelo gótico, pues es de planta exagonal con zócalo y cornisa salientes, y pilares con contrafuertes en los vértices que sobresalen ilusoriamente por encima de la cornisa; el contrafuerte va perforado en el costado por una ojiva, y lleva otras dos grabadas en el frente, con una hoja dispuesta sobre su tejadillo; en las caras frontal y trasera se sitúan los escudos reales flanqueados por las divisas del yugo y las flechas, mientras las caras laterales llevan sobrepuesta una hojarasca en relieve característica del momento (en ambos casos sobre huecos cajeados). Al no contener todavía el escudo el emblema de la granada, la pieza debe situarse antes de 1492. Es posible también en este caso que fuera una de las figuras de apóstoles realizadas en 1489 por encargo de la Reina, pero, en todo caso, de autor distinto al de la imagen de San Pablo. 